\title{
The Use of Technologies for Teaching Dentistry in Brazil: Reflections from an Integrative Review
}

\author{
Henrique Salustiano Silva ${ }^{1}$, Rita Catia Bariani ${ }^{2}$, Hatsuo Kubo ${ }^{2}$, Tais Pereira Leal ${ }^{2}$, Roberta Ilinsky ${ }^{2}$, \\ Thalita Borges ${ }^{2}$, Kurt Faltin Jr. ${ }^{2}$ \& Cristina Lucia Feijó Ortolani ${ }^{2}$ \\ ${ }^{1}$ Federal University of São Paulo, Brazil \\ ${ }^{2}$ University Paulista, Brazil \\ Correspondence: Cristina Lucia Feijó Ortolani, University Paulista, Brazil. E-mail: crisorto@gmail.com
}

Received: October 14, 2016

Accepted: November 30, 2016

Online Published: March 30, 2017

doi:10.5539/ies.v10n4p172

URL: https://doi.org/10.5539/ies.v10n4p172

\begin{abstract}
This article is an integrative review regarding the use of information and communication technologies (ICT) for teaching Dentistry. Thus, the article aimed to analyze papers that show the use of these technologies as resources and tools for learning. The stages in the elaboration of this integrative review were: establishing the guiding question and aims of the study, establishing the inclusion and exclusion criteria for articles, defining the research instrument and information to be extracted from the articles selected, results analysis, and discussion. For this, bibliographical data was collected from the SciELO, ColecionaSUS, and Periódicos CAPES databases in the search for articles published in the last five years, written in Portuguese, and containing the following keywords in Health Sciences: "education in dentistry", "dentistry", "dentistry informatics", "distance learning", and "education", and which were related in context to the topic of study. Eleven articles were selected as the results, which were analyzed using the data collection instrument. It was concluded that the current technologies used as teaching resources and tools contribute as allies for improving ways of teaching and learning, particularly in the area of dentistry, in a way that makes courses more interactive and dynamic, and adding personal and technical skills to the profiles of the professionals trained.
\end{abstract}

Keywords: technology, teaching, dentistry

\section{Introduction}

The academic environment in Dentistry still centers on traditional and face-to-face teaching. However, it should be noted that technological advances have improved the profession a lot. Digital photographs, digital x-ray, intraoral cameras, and electron microscopes are just some examples of the evolution in the working tools of professionals in this area (Coachman, 2012).

However, we are now in the era of technology, in which all fields of society are enriched by existing technological instruments, which arise to improve activities in all of these areas. With teaching this must also be the case. Today, technologies collaborate in better teaching-learning systems and allow for new teaching and learning models.

The use of technology has expanded in teaching institutions, especially in the area of health, which covers Dentistry, and in which the incorporation of new educational instruments can already be noted. In making this technology feasible, better conditions and greater resources for the teaching process are sought (Barra, Nascimento, Martins, Albuquerque \& Erdmann, 2006).

By using Technologies, among so many modifications that have arisen, the construction of new tools and educational resources of increasing value to Dentistry becomes possible, promoting interactivity, autonomy, and better understanding of contents studied.

In light of this, this study aimed to analyze the scientific papers available in the scientific literature regarding the use of technologies for teaching dentistry and their results in terms of learning.

\section{Method}

This study uses the integrative literature review method, which is an application that unites and summarizes scientific knowledge already set out in relation to the topic investigated; that is, it makes it possible to search for, 
examine, and summarize accessible evidence in order to cooperate in progressing knowledge on the topic. To construct this integrative review, the following stages were explored: establishing the guiding question (problem) and research objectives; composing the inclusion and exclusion criteria for the publications (sample selection); literature search; evaluating and listing the studies; reporting on and discussing the results (SOARES et al., 2014).

To conduct the study, the following question was formulated: What is the impact of using technologies for teaching dentistry?

Bibliographical data was collected from the LILACS, SciELO, ColecionaSUS, and PeriódicosCAPESdatabases. For the search criteria, documents published in the period covering 2011 to 2015 and which were found using the "advanced search" mode were used, together with the following Health Sciences keywords: "education in dentistry", "dentistry", dentistry informatics", "distance learning", and "education", and which presented a "title, abstract, and topic" that were consistent with the study objective. Among the documents found, only those that were written in Portuguese and had been published completely were considered.

An instrument for data collection was elaborated, with the aim of answering the guiding question in this review, and consisting of the following items: number, origin, title, author(s), year, considerations/themes, and keywords.

After examining the selected articles, there followed an analysis and organization of the topics: Technologies applied for teaching dentistry; Course curriculum structuring; Distance learning in dentistry.

\section{Results}

14 articles were found regarding the use of technologies for teaching dentistry. Of these, 11 were selected, since they fulfilled the established criteria. A characterization of the studies can be observed in chart 1 below.

\begin{tabular}{|c|c|c|c|c|c|c|}
\hline $\mathbf{N}^{\mathbf{0}}$ & Origin & Title & Authors & Year & Considerations/Themes & Keywords \\
\hline 1 & LILACS & $\begin{array}{l}\text { A Serious Game } \\
\text { proposal for } \\
\text { Teaching } \\
\text { Biosafety in } \\
\text { Dentistry }\end{array}$ & $\begin{array}{l}\text { PAIVA, P. V. de } \\
\text { F.; } \\
\text { MACHADO, } \\
\text { L. dos S.; } \\
\text { VALENÇA, A. } \\
\text { M. G.; } \\
\text { MORAES, R. } \\
\text { M. de. }\end{array}$ & 2013 & $\begin{array}{l}\text { Define the use of games } \\
\text { as an instrument } \\
\text { supporting the traditional } \\
\text { teaching method, via an } \\
\text { increase in student } \\
\text { learning stimulation. }\end{array}$ & $\begin{array}{l}\text { Exposure to } \\
\text { biological } \\
\text { agents; } \\
\text { Dentistry; } \\
\text { Informatics; } \\
\text { Education. }\end{array}$ \\
\hline 2 & LILACS & $\begin{array}{l}\text { Development of } \\
\text { animation for } \\
\text { dentistry as a } \\
\text { tool in the } \\
\text { educational } \\
\text { process }\end{array}$ & $\begin{array}{l}\text { JUNIOR, A. de } \\
\text { S. O.; } \\
\text { OLIVERIA, U. } \\
\text { da S.; } \\
\text { ANSELMO, } \\
\text { M. L.; } \\
\text { SANTOS, A. F. } \\
\text { dos; YARID, S. } \\
\text { D.; FILHO, I. } \\
\text { E. M. }\end{array}$ & 2014 & $\begin{array}{l}\text { Analyze the value of } \\
\text { animation, via } \\
\text { audiovisual language, as } \\
\text { a way of facilitating } \\
\text { learning. }\end{array}$ & $\begin{array}{l}\text { Animation; } \\
\text { audiovisual } \\
\text { media; } \\
\text { education. }\end{array}$ \\
\hline 3 & ColecionaSUS & $\begin{array}{l}\text { Teledentistry } \\
\text { center at the } \\
\text { faculty of } \\
\text { dentistry of the } \\
\text { University of } \\
\text { São Paulo: better } \\
\text { education for } \\
\text { better health in } \\
\text { times of ICT }\end{array}$ & $\begin{array}{l}\text { MACEDO, M. } \\
\text { C. S.; } \\
\text { ANTONIAZZI, } \\
\text { J. H.; WEN, C. } \\
\text { L.; ABDALA, } \\
\text { C. G.; } \\
\text { HADDAD, A. } \\
\text { E. }\end{array}$ & 2013 & $\begin{array}{l}\text { Describe the record of } \\
\text { papers written at the } \\
\text { Teledentistry Center of } \\
\text { the Faculty of Dentistry } \\
\text { of USP, and the results } \\
\text { achieved. }\end{array}$ & $\begin{array}{l}\text { Dentistry; } \\
\text { educational } \\
\text { technology; } \\
\text { public health. }\end{array}$ \\
\hline 4 & ColecionaSUS & $\begin{array}{l}\text { Experience of } \\
\text { the Brazilian }\end{array}$ & $\begin{array}{l}\text { HADDAD, A. } \\
\text { E.; }\end{array}$ & 2013 & $\begin{array}{l}\text { Define the use of } \\
\text { information and }\end{array}$ & $\begin{array}{l}\text { Telehealth; } \\
\text { Teledentistry; }\end{array}$ \\
\hline
\end{tabular}




\begin{tabular}{|c|c|c|c|c|c|c|}
\hline & & $\begin{array}{l}\text { teledentistry } \\
\text { network. }\end{array}$ & $\begin{array}{l}\text { RENDEIRO, } \\
\text { M.; } \\
\text { CORREIRA, } \\
\text { A. D. da M. S.; } \\
\text { BAVARESCO, } \\
\text { C. MORITA, } \\
\text { M. C.; } \\
\text { MACEDO, M. } \\
\text { C. S.; } \\
\text { Alexandra } \\
\text { MONTEIRO, } \\
\text { A. M. V. }\end{array}$ & & $\begin{array}{l}\text { communication } \\
\text { Technologies in distance } \\
\text { learning in dentistry via } \\
\text { training strategies to } \\
\text { support the establishment } \\
\text { of Teledentistry centers. }\end{array}$ & $\begin{array}{l}\text { distance } \\
\text { learning. social } \\
\text { networks. }\end{array}$ \\
\hline 5 & CAPES & $\begin{array}{l}\text { Evaluation of } \\
\text { distance learning } \\
\text { in the } \\
\text { undergraduate } \\
\text { course in } \\
\text { dentistry }\end{array}$ & $\begin{array}{l}\text { SILVA, H. E. } \\
\text { C. da.; } \\
\text { SANTOS, G. } \\
\text { N. M.; }\end{array}$ & 2014 & $\begin{array}{l}\text { Determine the } \\
\text { importance of distance } \\
\text { learning in dentistry } \\
\text { course curriculums and } \\
\text { lay out experiences with } \\
\text { the application of } \\
\text { informatics in health for } \\
\text { teaching dentistry in the } \\
\text { last thirteen years. }\end{array}$ & $\begin{array}{l}\text { Continued } \\
\text { learning in } \\
\text { dentistry; } \\
\text { curriculum; } \\
\text { education in } \\
\text { dentistry; } \\
\text { distance } \\
\text { learning. }\end{array}$ \\
\hline 6 & ColecionaSUS & $\begin{array}{l}\text { Application } \\
\text { based on Cavity } \\
\text { determinants to } \\
\text { support decision } \\
\text { making }\end{array}$ & $\begin{array}{l}\text { WARMILING, } \\
\text { A. M. F.; } \\
\text { AMANTE, C. } \\
\text { J.; VIERIRA, } \\
\text { L. M. H.; } \\
\text { Milton, M. V. } \\
\text { H. Vieira, Ana } \\
\text { Lúcia MELLO, } \\
\text { A. L. F. S. }\end{array}$ & 2012 & $\begin{array}{l}\text { Analyze informatics in } \\
\text { health via an application } \\
\text { as a support instrument } \\
\text { for teaching dentistry } \\
\text { using the approaches of } \\
\text { innumerous topics that } \\
\text { are important for } \\
\text { professionals. }\end{array}$ & $\begin{array}{l}\text { Dentistry } \\
\text { informatics; } \\
\text { Dental Cavity; } \\
\text { Dentistry } \\
\text { Education. }\end{array}$ \\
\hline 7 & ColecionaSUS & $\begin{array}{l}\text { Learning } \\
\text { Material; } \\
\text { Professional } \\
\text { skills for health } \\
\text { professionals and } \\
\text { e-learning: } \\
\text { studies to } \\
\text { develop a } \\
\text { taxonomy }\end{array}$ & $\begin{array}{l}\text { BRASIL, L. } \\
\text { B.; MACEDO, } \\
\text { M. C. S.; } \\
\text { CAMPOS, F. } \\
\text { E.; HADDAD, } \\
\text { A. E. }\end{array}$ & 2013 & $\begin{array}{l}\text { Evaluate the use of } \\
\text { Learning material from } \\
\text { the } S U S \text { Open University } \\
\text { collection and determine } \\
\text { the creation of a } \\
\text { taxonomy to define this } \\
\text { material in the field of } \\
\text { health. }\end{array}$ & $\begin{array}{l}\text { Learning } \\
\text { material; } \\
\text { e-learning; } \\
\text { information } \\
\text { and } \\
\text { communication } \\
\text { technologies; } \\
\text { prismatic } \\
\text { attention to } \\
\text { health, } \\
\text { dentistry. }\end{array}$ \\
\hline 8 & LILACS & $\begin{array}{l}\text { The teaching of } \\
\text { bioethics: } \\
\text { student } \\
\text { evaluation via } \\
\text { internet } \\
\text { discussion } \\
\text { forums }\end{array}$ & $\begin{array}{l}\text { JUNQUEIRA, } \\
\text { C. R.; SILVA, } \\
\text { P. M. T. da; } \\
\text { JUNQUEIRA, } \\
\text { S. R; RAMOS, } \\
\text { D. L. de P. }\end{array}$ & 2012 & $\begin{array}{l}\text { Differentiate the use of } \\
\text { discussion forums in a } \\
\text { virtual learning } \\
\text { environment from } \\
\text { traditional face-to-face } \\
\text { study, via a qualitative } \\
\text { survey of student } \\
\text { perceptions of this study } \\
\text { model. }\end{array}$ & $\begin{array}{l}\text { Dentistry } \\
\text { education; } \\
\text { bioethics; } \\
\text { distance } \\
\text { learning. }\end{array}$ \\
\hline 9 & SCIELO & $\begin{array}{l}\text { The portfolio as } \\
\text { a facilitating } \\
\text { strategy for the } \\
\text { teaching-learning }\end{array}$ & $\begin{array}{l}\text { FROTA, M. M. } \\
\text { A.; } \\
\text { MENEZES, L. } \\
\text { M. B. de; }\end{array}$ & 2011 & $\begin{array}{l}\text { Evaluate the use of the } \\
\text { portfolio tool as a } \\
\text { learning instrument in } \\
\text { Dentistry training via a }\end{array}$ & $\begin{array}{l}\text { Teaching; } \\
\text { education in } \\
\text { Dentistry; } \\
\text { Educational }\end{array}$ \\
\hline
\end{tabular}




\begin{tabular}{|c|c|c|c|c|c|c|}
\hline & & $\begin{array}{l}\text { process in } \\
\text { dentistry } \\
\text { training. } \\
\text { Suitability of } \\
\text { teaching } \\
\text { methods using a } \\
\text { virtual learning } \\
\text { environment. }\end{array}$ & $\begin{array}{l}\text { ALENCAR, C. } \\
\text { H.; JORGE, L. } \\
\text { da S.; } \\
\text { ALMEIDA, M. } \\
\text { E. L. de. }\end{array}$ & & $\begin{array}{l}\text { virtual learning } \\
\text { environment and describe } \\
\text { the positive evaluation of } \\
60 \text { students in two } \\
\text { disciplines, with portfolio } \\
\text { evaluation as an } \\
\text { evaluation method. }\end{array}$ & evaluation. \\
\hline 10 & ColecionaSUS & $\begin{array}{l}\text { TelessaúdeBrasil } \\
\text { Networks and } \\
\text { Teledentistry; } \\
\text { report on the } \\
\text { experience in } \\
\text { MatoGrosso do } \\
\text { Sul }\end{array}$ & $\begin{array}{l}\text { CORREIRA, } \\
\text { A. D. da M. S.; } \\
\text { DOBASHI, B. } \\
\text { F.; } \\
\text { GONÇALVES, } \\
\text { C. C. M.; } \\
\text { KANOMATA, } \\
\text { M. N.; } \\
\text { MONREAL, V. } \\
\text { R. F. D.; } \\
\text { NUNES, E. A. }\end{array}$ & 2013 & $\begin{array}{l}\text { Define the use of } \\
\text { informatics in health via } \\
\text { Teleducation in Dentistry } \\
\text { applied in seminars and } \\
\text { defending its use as an } \\
\text { optimizing tool for } \\
\text { dentistry teaching. }\end{array}$ & $\begin{array}{l}\text { Dentistry; } \\
\text { Teledentistry; } \\
\text { Teleconsulting; } \\
\text { Teleducation; } \\
\text { Primary } \\
\text { Healthcare. }\end{array}$ \\
\hline 11 & LILACS & $\begin{array}{l}\text { Atraumatic } \\
\text { Restorative } \\
\text { Treatment } \\
\text { (ART): training } \\
\text { course based on } \\
\text { Education } \\
\text { Supported by } \\
\text { Technology }\end{array}$ & $\begin{array}{l}\text { LOVATO, P. } \\
\text { R.; RAGGIO, } \\
\text { D. P.; LUNG, } \\
\text { C. W.; } \\
\text { HADDAD, A. } \\
\text { E.; } \\
\text { CAMARGO, } \\
\text { L. B. }\end{array}$ & 2012 & $\begin{array}{l}\text { Evaluate the } \\
\text { effectiveness of dentistry } \\
\text { training based on } \\
\text { teaching supported by } \\
\text { technology. Lay out the } \\
\text { result for the participating } \\
\text { students' level of learning } \\
\text { and the need for } \\
\text { association with other } \\
\text { teaching-learning } \\
\text { strategies for } \\
\text { undergraduates. }\end{array}$ & $\begin{array}{l}\text { Dentistry } \\
\text { education; } \\
\text { distance } \\
\text { learning; } \\
\text { atraumatic } \\
\text { restorative } \\
\text { treatment. }\end{array}$ \\
\hline
\end{tabular}

Regarding the articles selected, Table 1 presents the distribution of them according to their origins.

Table 1. Distribution of publications selected from the databases and electronic library

\begin{tabular}{lcc}
\hline \multirow{2}{*}{ Database and Electronic Library } & \multicolumn{2}{c}{ Publications selected } \\
\cline { 2 - 3 } & $(\mathrm{n})$ & $(\%)$ \\
\hline SCIELO & 1 & $9 \%$ \\
LILACS & 4 & $37 \%$ \\
ColecionaSUS & 5 & $45 \%$ \\
Capes & 1 & $9 \%$ \\
Total & 11 & $100 \%$ \\
\hline
\end{tabular}

With regards to time of publication, it was found that the year that presented the greatest number of articles published was 2013 , with five publications, corresponding to $45.45 \%$ of the publications included; this was followed by 2012, with three publications, which corresponds to $27.27 \%$. 2014 has two publications, which corresponds to $18.18 \%$, and 2011 has one publication, which represents $9.09 \%$ of publications.

The studies selected were classified regarding their publication category, as expressed by the journals, thus specifying: $54.54 \%$ (6) original studies, $27.27 \%$ (3) experience reports, and $18.18 \%$ (2) literature review studies.

\section{Discussion}

\subsection{Applications, Games, and Audiovisual Resources}

The use of information and communication technologies in dentistry referred to in articles 1, 2, and 6 , 
demonstrates valuation in knowledge construction for dentistry teaching. The different forms of application geared towards this area, such as applications, games, and audiovisual resources, are totally applicable.

There is potential for using applications based on information and communication technology as a tool for teaching dentistry, helping in the teaching-learning process, in diagnosing cavities, for example, and in new constructions using existing technologies to provide students with technical abilities and behavioral skills, such as the ability to innovate, creativity, autonomy, and better communication. This needs to be intensified by teaching staff and institutions as a new teaching methodology involving the use of technologies and producing learning that generates results in society and applicability in dentistry practice (Warmiling, Amante, Vieira, \& Mello, 2012).

The use of technology via computer games contributes to the learning process and stimulates the advancement of new behavioral skills. Moreover, its use coupled with the opportunity to carry out simulations of daily occurrences reduces costs and also makes the dissemination of knowledge feasible in a more interactive and didactic way (Paiva, Machado, Valença, \& Moraes, 2013).

The use of audiovisual resources, such as animations, has been of the upmost importance in application for better assimilation of knowledge, since it uses a language the students are more comfortable with, and provides understanding without the need to reproduce an imagined reality, and generates a message that the professor wishes to convey that goes beyond verbal language (Junior et al., 2014).

\subsection{Course Curriculum Structuring}

Similarly, articles 3 and 4 referred to the lack of restructuring in course curriculums in the area of dentistry in order to include a program that addresses the application of technology in professional practice.

Related to course curriculum structures, experience would defend offering a Teledentistry discipline in undergraduate and post-graduate dentistry course programs, since it prepares future professionals to apply techniques that use technology in their daily activities and improves their experience of Teledentistry and use of the technologies (Macedo, Antoniazzi, Wen, Abdala, \& Haddad, 2013).

Also in relation to this topic, with the experience and application of teledentistry, a lack of student preparation for a new professional practice model was noted, in which training for multidisciplinary teamwork and not only consultations has been demanded (Haddad et al., 2013).

\subsection{Distance Learning Applied to Dentistry}

Based on the assumptions listed, articles 5, 7, 8, 9, and 10 indicate the need to use a distance learning modality to incorporate technologies in their innumerous forms, such as those highlighted, and via the resources and tools available in virtual learning environments.

The use of distance learning results in learning advancements for health professionals, especially those from the area of dentistry, due to it providing learning in accordance with their needs, time available, and training location. With this, the use of educational resources is guaranteed which are constructed via current technologies and which are targeted and aligned with the skills required, via the use of a taxonomy that reproduces and connects pedagogical, technological, and practical aspects in training services for these professionals (Brasil, Skelton-Macedo, Campos, \& Haddad, 2013).

The use of the internet applied to dentistry education, especially in the use of teaching platforms in higher graduation courses, has been an instrument for advancing teaching quality. These platforms also contribute as spaces for collaboration and adjustment to social changes regarding digital changes in ways of teaching and learning (Silva \& Santos, 2014).

The use of distance learning technological resources, via the portfolio tool, based on experience, is defended for dentistry teaching, based on student gains in autonomy and the guarantee of interaction between the subjects involved, as well as stimulating creativity and research. Moreover, the whole process of using this tool provides active and safe communication between participants, in which it facilitates the teaching-learning process and strengthens dentistry teaching (Frota, Menezes, Alencar, Jorge, \& Almeida, 2011).

The use of a discussion forum as a distance learning tool was shown to be useful in producing learning in the area of dentistry by sharing knowledge between students, professors, and tutors, as well as allowing real cases to be laid out in order to enrich virtual discussions (Junqueira, Junqueira, \& Ramos, 2012).

Regarding the use of information and communication technologies in permanent dentistry education, distance learning resources (DL), via the simulation of practical exercises, and Teleducation, via the application of virtual seminars, demonstrates the potential of these tools in the educational environment, and also allows broad access 
for professionals in a synchronous or asynchronous way to the Teledentistry service (Correira et al., 2013).

Education supported by technologies contributes to improving the field of dental treatment via a new teaching proposal that is able to reach a great number of students and professionals who live far from large centers, whether by the use of digital media or virtual environments (Lovato, Raggio, Lung, Haddad, \& Carmargo, 2012).

\section{Conclusion}

In this investigation, studies were found that describe, verify, and characterize the potentialities that exist in the use of technologies for teaching dentistry. It was verified that the potential technologies exist via the use of digital resources and tools, virtual learning environments, and the introduction of specific disciplines in courses, since students have little familiarity with these technologies.

It is hoped that the knowledge revealed by this study can widen the possibilities of better Dentistry course organization, with the aim of making the teaching environment more productive and interactive. It is also hoped that strategies that support the student are used in courses, since this can have an influence on their learning, bringing benefits to this new teaching and learning model.

The proposed objective was achieved, given that it was possible to identify knowledge produced regarding the use of technologies for teaching dentistry, analyzing the main technologies involved in the learning process in this area and also identifying the skills that can be applied with the use of the resources and tools explored. This information showed that technologies applied to teaching dentistry are conceived as instruments that act in constructing links between theory and practice, exerting constant movement towards constructing skills.

The use of the integrative review methodology was significant in achieving the objective and identifying gaps that imply the need for investigations designed to develop evidence related to the theme studied. Thus, studies could collaborate by creating research and knowledge in Dentistry, thus supporting improvements in dentistry teaching and the profile of students trained.

\section{References}

Barra, D. C. C. et al. (2006). Evolução histórica e impacto da tecnologia na área da saúde e da enfermagem. Rev. Eletr. Enf, 8(3), 422-430. Retrieved from http://www.fen.ufg.br/revista/revista8_3/v8n3a13.htm

Brasil, L. B. et al. (2013). Objetos de Aprendizagem, Competências Profissionais para Profissionais de Saúde e e-Learning: Estudos para Desenvolvimento de uma Taxonomia. J Bras Tele, 2(2), 24-28. https://doi.org/10.12957/jbrastele.2013.8169

Coachman, C. (2012). A internet abrindo novas perspectivas para profissionais da Odontologia. Revista Gutierre Odontolife, $\quad 53, \quad 1-15 . \quad$ Retrieved from: $<$ http://digitalsmiledesign.com/static/media/Coachman_Entrevista_ISTOE.pdf $>$ Accessed on August 23 2016.

Correia, A. B. et al (2013). Telessaúde Brasil redes e teleodontologia: relato da experiência en Mato Grasso do Sul. J Bras Tele, 2(2), 87-89. https://doi.org/10.12957/jbrastele.2013.8137

Da Silva, H. E. C., \& Santos, G. N. M. (2014). Avaliação do ensino a distância no curso de graduação em odontologia. Gestão e Saúde, 5(2), 670-685. Retrieved from http://gestaoesaude.unb.br/index.php/gestaoesaude/article/view/620/pdf

Frota, M. M. A. et al. (2011). O portfólio como estratégia facilitadora do processo de ensino-aprendizagem para a formação em odontologia: Adequação de metodologias de ensino utilizando o ambiente virtual de aprendizagem. Rev. ABENO, Londrina, 11(1). $\quad$ Retrieved from https://revabeno.emnuvens.com.br/revabeno/article/viewFile/34/34

Haddad, A. E. et al. (2013). Experiência da rede brasileira de teleodontologia. J Bras Tele, 2(2), 81-83. https://doi.org/10.12957/jbrastele.2013.8133

Junior, A. de S. O. et al (2014). Desenvolvimento de animação para a odontologia como ferramenta no processo educacional. RFOUPF, 19(3). Retrieved from http://seer.upf.br/index.php/rfo/article/view/3861/3296

Junqueira, C. R. et al. (2012). O ensino de bioética: avaliação discente por meio de fóruns de discussão na Internet. Actabioeth, 18(1), 93-100. http://dx.doi.org/10.4067/s1726-569x2012000100008

Lovato, P. R. et al. (2012). Tratamento Restaurador Atraumático (ART): curso de treinamento baseado em Educação Apoiada em Tecnologia. Rev. Assoc. Paul. Cir. Dent, 66(3). Retrieved from http://revodonto.bvsalud.org/pdf/apcd/v66n3/a09v66n3.pdf 
Macedo, M. C. S. et al. (2013). Núcleo de teleodontologia da faculdade de odontologia da Universidade de São Paulo: Uma melhor educação para uma melhor saúde em tempos de TIC. J Bras Tele, 2(2), 33-34. Retrieved from http://www.jbtelessaude.com.br/jornal/volume/download_artigo/589

Paiva, P. V. F. et al. (2013). Uma Proposta de Serious Game para o Ensino de Biossegurança em Odontologia. Pesquisa Brasileira em Odontopediatria e Clínica Integrada, 13(2), 135-139. http://dx.doi.org/10.4034/PBOCI.2013.132.00

Soares, C. B. et al. (2014). Revisão integrativa: conceitos e métodos utilizados na enfermagem. Rev. esc. enferm. USP, 48(2), 335-345. http://dx.doi.org/10.1590/S0080-6234201400002000020

Warmling, A. M. F. et al. (2012). Aplicativo Baseado nos Determinantes da Doença Cárie para Apoio à Tomada de Decisão. J Bras Tele, 1(2), 36-42. http://dx.doi.org/10.12957/jbrastele.2012.6406

\section{Copyrights}

Copyright for this article is retained by the author(s), with first publication rights granted to the journal.

This is an open-access article distributed under the terms and conditions of the Creative Commons Attribution license (http://creativecommons.org/licenses/by/4.0/). 